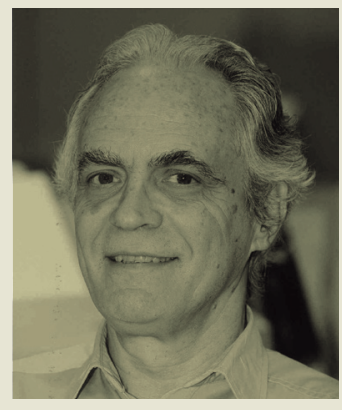

\title{
2013: CRESCIMENTO OU ESTAGNAÇÃO?
}

(U) ma decolagem perfeita nada garante se o piloto não souber onde pousar. Na dúvida, melhor não decolar. Na incerteza, melhor não investir. Sabemos que a produção e seus desdobramentos - salários, lucros, rendas dependem do binômio consumo e investimento.

Mesmo que o consumo esteja bombando, um horizonte vacilante não faz o investimento sair do casulo. Se uma das lâminas estiver cega, a tesoura não corta. A pergunta então é: por que, com tantos estímulos ao consumo - redução de impostos, baixa nos juros, represamento de preços (combustíveis, por exemplo) - os investimentos não crescem?

Vários fatores conspiram contra essa esperada retomada. A crise internacional, que contrai a demanda na Europa, na Ásia e também nos Estados Unidos, acirra a concorrência e torna mais difícil nossas exportações, especialmente de manufaturados. Uma taxa de câmbio ainda valorizada completa o desalento, e a indústria brasileira encolhe como consequência. A expansão da demanda interna, alavancada pelo crescimento da renda nos últimos anos, provoca elevação de preços do que não pode ser importado: a maioria dos serviços. Não dá, por exemplo, para cortar o cabelo em Londres. Só os mais riquinhos conseguem... A quebra de safras nos Estados Unidos gera aumento dos preços de alguns alimentos.

Diante dessas pressões inflacionárias que ameaçam estourar a meta, o governo brasileiro adota uma política perigosa: solta a tartaruga e segura a gazela, ou seja, freia alguns preços, como o dos combustíveis (penalizando a capacidade de investimento da Petrobras), reduz os impostos sobre bens de consumo e encolhe seus valores. Claro, em ano de eleição a caixa de ferramentas da bondade é escancarada, mas não se pode agir assim o tempo todo, e os investidores sabem disso; sabem que as pressões inflacionárias estão sendo contidas artificialmente. Embora necessária para evitar o pior, essa política não é sustentável no médio prazo. A ofensiva para baratear a energia elétrica para empresas e consumidores, desonerando as tarifas de taxas e depreciações já terminadas, pode afetar os novos investimentos. Várias empresas do setor estão tirando o corpo depois do anúncio das novas regras.

Como é de ofício, o governo promete um crescimento de 4 ou $4,5 \%$ do PIB brasileiro em 2013. Já assistimos a esses efeitos pirotécnicos em anos anteriores. $\mathrm{O}$ crescimento dependerá da expansão dos investimentos, os quais as condições externas não ajudam e as internas, em certa medida, atrapalham. Aliás, especialmente na Europa, o ranger de dentes da população castigada pelo desemprego e pela perda de direitos já causa confrontos nas ruas, situação que não inspira o mínimo de otimismo. Em matéria de crescimento do PIB, o primeiro biênio do atual mandato presidencial é um dos piores das últimas décadas. Diante das circunstâncias, 2013 parece se inclinar mais para repetir 2012 do que para um desenvolvimento robusto da produção. 